\title{
地方空港アクセスが広域的利用に与える影響*
}

\section{Local Airport Usage from Wider Area Affected by Access Service *}

村上直樹** ・枦元淳平 $* * *$ ・奥村 誠**** ・ 塚井誠人 $* * * * *$

By Naoki MURAKAMI • Junpei HAZEMOTO $\cdot$ Makoto OKUMURA $\cdot$ Makoto TSUKAI

\section{1. はじめに}

国内航空の自由化に伴うサービス改善とネットワーク の拡充により、わが国の長距離旅客交通においては、航 空が主要な交通手段となっている。しかしながら、地方 生活圈のすべてが空港を持つわけではなく、またすべて の空港の相互に十分な便数のフライトサービスが提供さ れているわけではない。そのため、羽田空港において国 内便を乗り継いだり 、地方生活圈を越えて少し離れた 空港に出向いて便数の多い路線を利用するという広域的 な利用行動 ${ }^{2}$ が存在する。本研究ではまず、第 2 回幹線 旅客純流動調查（1995 年実施）のデータを集計し、わが 国におけるこのような広域的な空港利用の実態を明らか にする。

都市間トリップのサービスは、幹線部分の主要交通手 段ばかりでなく、アクセス部分をも含めた出発地から到 着地までの全てのサービスのレベルに左右される ${ }^{3)}$ 。旅 行者の真の OD を把握できる幹線旅客純流動調査デー夕 が整備されたことにより、アクセス部分を含むラインホ ールのサービスレベルを取り込んだ航空と鉄道の機関分 担モデルが作成されるようになった 4,5)。これらの研究で は、直行の航空便と鉄道との選択がある ODに着目して 分析を行っており、冒頭に述べような少し離れた空港 を利用するマルチモーダル経路については議論されてい ない。

一方、ラインホール全体の信頼性を高めることが空港 の利用にとって重要であることから、空港整備事業の費 用対効果分析マニュアルの中にも軌道系アクセスが位置 つけられの、アクセス交通の利便性を評価する研究》や、 アクセス手段分担モデルの研究 ${ }^{83.99}$ の中には新幹線を利 用した中距離のアクセスの可能性に言及したものもある。

*キーワーズ: 航空旅客、空港アクセス、国土計画

**学生員、広島大学大学院工学研究科

(広島県東広島市鏡山1-4-1、TEL·FAX 082-424-7827)

***正員、修 (工)、岡山罧了可新地方振興局

(岡山県新見高尾2400、TEL 0867-72-1177)

****正員、博(工)、広島大学大学院工学研究科

***** 正員、博(工)、立命館大学理工学部都市システム工学科 (滋賀県草津市野路東 1-1-1 TEL 077-561-5986)
しかしこれらの分析では、利用する空港は先決されてお り、空港アクセス整備により主要交通機関の分担率や利 用空港が変化するという視点は見られない。また空港の 選択を扱った既存研究 ${ }^{10}$ は千歳と丘珠といったように一 つの都市圈に存在する空港間の選択を念頭においており、 広域的な利用という観点は乏しい。

既存の機関分担モデル23,344)から、航空サービスにおい ては便数が重要な要素となっていることがわかる。地方 空港において今後便数を維持するためには他都市圈から の旅客を集めることが必要となる。広島空港は中国地方 の拠点空港としての位置付けを持たせるために 1993 年 に移転開港したが、広島の都心から遠く離れており、他 の地方生活圈からやって来る旅客に対して利用しづらく なっている。

本研究では、中国地方における各空港の利用実態を明 らかにした上で、広島空港において現在構想されている アクセス鉄道整備に関するシミュレーションを行い、周 辺の都市圏からの広域利用に及ぼす影響を分析する。

\section{2. 国内航空トリップの分類}

近年国内航空サービスが充害したものの、すべての地 方都市圈が空港を持つわけではなく、またフライトが提 供されている空港のペアは限られている。そこで第2回 幹線旅客純流動調查 (1995 年実施) の航空利用客の個票 データを、その OD の間での航空サービスの有無によっ て分類する。

最初に各ゾーン (207 生活圈) に対して定期便の就航 する最近隣空港を特定する。その上で $\mathrm{OD}$ ペアを以下の 4 つに分類する。

(1) 両ゾーンの最近隣空港の間に直行のフライトがあ る。

(2) 直行のフライトはないが、出発地から最近隣ではな い別の空港まで行けば到着地の最近隣空港までの フライトがある。

(3) 直行のフライトはないが、出発地の最近隣空港から 到着地の最近隣ではない空港までのフライトが存 在する。

(4) 以上の (1) (3)のようなフライトが存在しない。航 
表1 航空サービスの形態-基づく OD ペアの分類

\begin{tabular}{|c|c|c|r||r|}
\hline OD分類 \利用形態 & (1)のみ & $(2),(3)$ を含む & \multicolumn{1}{|c|}{$(4)$ を含む } & \multicolumn{1}{|c|}{ 計 } \\
\hline OD分類(1) & $1,764(33 \%)$ & $1,185(22 \%)$ & $54(1 \%)$ & $3,005(56 \%)$ \\
OD分類(2),(3) & - & $1,919(36 \%)$ & $241(5 \%)$ & $2,160(41 \%)$ \\
OD分類(4) & - & - & $163(3 \%)$ & $163(3 \%)$ \\
\hline \hline 計 & $1,764(33 \%)$ & $3,104(58 \%)$ & $460(8 \%)$ & 5,328 \\
\hline
\end{tabular}

表2 OD 分類ごとの航空利㶲形態別旅客数 (人年)

\begin{tabular}{|c|c|c|r||r|}
\hline OD分類 利用形態 & $(1)$ & \multicolumn{1}{|c|}{$(2),(3)$} & \multicolumn{1}{|c|}{$(4)$} & \multicolumn{1}{|c|}{ 計 } \\
\hline OD分類(1) & $26,809,823(67.7 \%)$ & $5,444,695(13.8 \%)$ & $69,144(0.2 \%)$ & $32,323,662(81.7 \%)$ \\
OD分類(2),(3) & - & $6,635,374(16.8 \%)$ & $406,761(1.0 \%)$ & $7,042,135(17.8 \%)$ \\
OD分類 $(4)$ & - & - & $216,119(0.5 \%)$ & $216,119(0.5 \%)$ \\
\hline \hline 計 & $26,809,823(67.7 \%)$ & $12,080,069(30.5 \%)$ & $692,024(1.7 \%)$ & $39,581,916$ \\
\hline
\end{tabular}

空を利用するためには、出発地から最近隣ではない 空港までアクセスし、到着地の最近隣ではない空港 までを利用することになる。

表-1 に ODペアの分類結果を示す。1995 年では航空の 利用が見られた OD ペアは 5,328 あり、そのうち 3,005 の $\mathrm{OD}$ ペアが直行便を持つ分類(1)に当たる $(56 \%)$ 。分 類(2)または(3)に相当する OD ペアは 2,160（41\%）を占 め、航空需要はあるが直行便のない区間も多いことがわ かる。分類(4)に含まれるのは 163 の OD ペア (3\%) に 過ぎない。このことは需要に合わせる形で航空サービス が提供されていると考えることができるが、逆にフライ トサービスが提供されていない都市圏の間では航空の利 用がなされないことの結果である可能性もある。

表-2には、OD ペアの分類別に、航空旅客の利用形態 ごとの比率を集計した結果を示す。これより、分類(1)の 直行便が存在する OD ペアであっても(2),(3)のような利 用形態が無視できないほどの量含まれていることがわか る。

\section{3. 経路選択行動の分析}

\section{（1）経路選択の実態}

1995 年純流動調査のデータを用いて、先の分類(1)の $\mathrm{OD}$ ペアのうちで、最近隣の空港を用いる前述の(1)の直 通航空経路、最近隣ではない空港を経由する前述の(2)、 (3)の経路（以下マルチモーダル経路）、鉄道のみを利用 した経路（鉄道経路）の3 経路の利用実績がある $\mathrm{OD}$ ヘ アを抽出した。その結果として 460 の ODペアが抽出さ れた。これは、鉄道と航空の利用実績がある ODペアの $5.5 \%$ にあた、鉄道距離で測った OD の平均距離は約 $897 \mathrm{~km}$ でほぼ東京-広島間 $(894 \mathrm{~km})$ に相当する。

鉄道距離に基づく距離帯ごとの 3 経路の分担率を図-1 に示す。距離が増すごとに直通航空経路の分担率が増加 している。マルチモーダル経路の分担率も 800-1000km 帯を除き距離が増すほど増加している。800-1000km 帯で

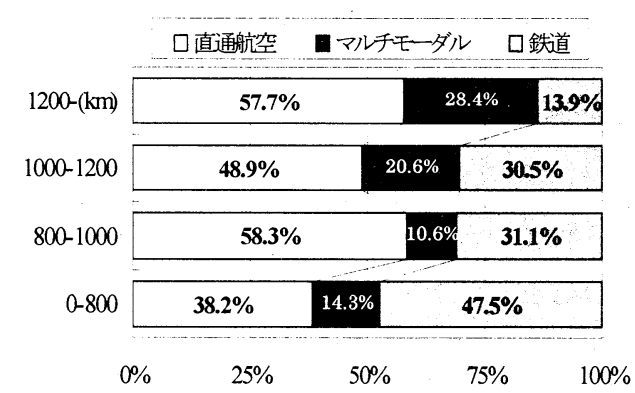

図-1＼cjkstart距離帯別に見た 3 経路の分担率



図-2３経路のサービスレベルの比較 （直通航空を 1 とする）

は周囲に有力な航空経路が少ない大都市圏を出発または 目的地とする OD を多く含むため、マルチモーダル経路 の分担率が低くなっている。

図-2に、マルチモーダルおよび鉄道経路のサービス水 準を直通航空経路に対して比較した結果を示す。ここで の運行本数は、その経路に含まれる区間の中で最も運行 本数の少ない区間の運行本数を用いて評価する。また、 経路の所要時間は、その経路を構成する各リンクの所要 時間の合計に、航空利用の経路であれば待ち時間や乗り 継ぎを考慮するため 40 分を加えた值を用いる。各リンク の所要時間は、JR 時刻表(1995 年)より与えた。

所要時閒は直通航空、マルチモーダル、鉄道の各経路 の順に短いが運賃は逆に直通航空経路が最も高い。運行 本数はマルチモーダル経路や鉄道経路が多い。

すなわち、直通航空経路の代替経路としては、少し時 間は掛かるが同程度の運賃で運行本数が多く、スケジュ 
ールを立てやすいマルチモーダル経路が利用される傾向 がある。

（2）経路選択のモデル化

直通航空、マルチモーダル、鉄道の3つの経路につい て、非集計ロジット型の経路選択モデルを構筑した。旅 行目的によってサービスレベルに対する感度が異なるた め、目的別にパラメータを置き推定した。なお、推定に あたっては個票の拡大係数に比例する重みをつけた重み 付き最尤推定法を用いた。

定式化を式(1),(2)に示し、表-3に推定結果を示す。モデ ルの適合度を表す尤度比は比較的高く、論理矛盾のない 有意なパラメータが得られた。

目的別にみると、所要時間のパラメータの推定値は「仕 事、「その他」目的で大きく、「観光」目的では小さい。 運賃のパラメータの大きさは「その他、「仕事、「観光」 の順である。両者のパラメータにより算出した時間価值 は「仕事」が 3,800 円/時と高く、「観光」が 1,400 円/時であ る。運行本数のパラメータ推定値は「仕事」目的が最も大 きく、ビジネス旅客はスケジュールの立てやすい交通機 関を選択寸る傾向にある。観光」目的では全体的にパラ メータ值、 $\mathrm{t}$ 值ともに小さいことから、ルートの乗り心 地などここでとりあげた時間、運賃、運行本数以外の要 因の影響が大きい。対照的に私用や帰省などを含んでい る「その他」の目的では、パラメー夕值、 $\mathrm{t}$ 值ともに大き くここでとりあげた要因の影響力が全体的に強いことを 示している。また、選択肢固有の定数項から、マルチモ 一ダル経路の効用が低く評価されており、乗り換え抵抗 の存在が疑われる。

$$
P^{i}=\frac{\exp \left(V_{i}\right)}{\sum_{I} \exp \left(V_{i}\right)}
$$

$P^{i} \quad$ : 経路 $i$ を選択寸る確率

$$
V_{i}=\sum_{j}\left(\beta_{j} x_{i, j}\right)
$$

$$
\begin{array}{ll}
V_{i} & \text { : 経路 } i \text { の効用の確定項 } \\
x_{j} & \text { : 各説明変数 } \\
\beta_{j} & \text { : 各パラメータ } \\
j & \text { : 説明変数のインデックス }
\end{array}
$$

\section{4. 地方空港の広域的利用の実態}

\begin{tabular}{|c|c|c|c|c|}
\hline \multicolumn{2}{|c|}{ パラメータ } & \multicolumn{2}{|l|}{ 推定値 } & t值 \\
\hline & (仕事) & -0.59 & ** & -19.23 \\
\hline \multirow[t]{3}{*}{ 所要時間(100分) } & （観光） & -0.18 & $* *$ & -6.04 \\
\hline & (その他) & -0.66 & $* *$ & -16.08 \\
\hline & (仕事) & -0.93 & $* *$ & -15.88 \\
\hline \multirow[t]{2}{*}{ 運賃(万円) } & （観光） & -0.80 & $* *$ & -10.41 \\
\hline & (その他) & -2.15 & $* *$ & -19.24 \\
\hline & (仕事) & 0.06 & $* *$ & 28.56 \\
\hline \multirow[t]{3}{*}{ 運行本数 (本/日) } & （観光） & 0.03 & $* *$ & 10.52 \\
\hline & (その他) & 0.05 & $* *$ & 14.53 \\
\hline & $0-800$ & 0.75 & $* *$ & 13.12 \\
\hline 定数項 & $800-1000$ & 0.89 & $* *$ & 11.08 \\
\hline \multirow[t]{3}{*}{ （直通航空） } & $1000-1200$ & 0.53 & $* *$ & 5.19 \\
\hline & $1200-(\mathrm{km})$ & 1.32 & $* *$ & 11.78 \\
\hline & $0-800$ & -0.17 & $* *$ & -2.97 \\
\hline 定数項 & $800-1000$ & -0.37 & $* *$ & -4.04 \\
\hline \multirow[t]{2}{*}{ (マルチモーダル) } & $1000-1200$ & -0.11 & & -1.07 \\
\hline & $1200-(\mathrm{km})$ & 0.01 & & 0.15 \\
\hline \multicolumn{2}{|c|}{ 初期尤度 } & \multicolumn{3}{|c|}{-15535} \\
\hline \multicolumn{2}{|c|}{ 最終尤度 } & \multicolumn{3}{|c|}{-12536} \\
\hline \multicolumn{2}{|c|}{ 自由度調整済み尤度比 } & \multicolumn{3}{|c|}{0.193} \\
\hline \multicolumn{2}{|c|}{ サンプル数 } & \multicolumn{3}{|c|}{14141} \\
\hline \multirow{3}{*}{ 時間価値(円/時) } & (仕事) & \multicolumn{3}{|c|}{3815} \\
\hline & （観光） & \multicolumn{3}{|c|}{1379} \\
\hline & (その他) & \multicolumn{3}{|c|}{1857} \\
\hline
\end{tabular}

\section{（1）利用形窇思门旅各数の集計}

広島空港を初めとする中国地方の空港と福岡空港につ いて、2.で行った航空サービスの利用形態の集計を行 った結果を表-4に示す。利用形態(1)の旅客は直行便を利
表-3 3 経路選択モデルの推定結果

用するためにその空港を利用している客である。これに 対して利用形態(2),(3)の旅客はより高いサービスを求め てその空港を経由するルートをわざわざ選択した客であ ると考えることができる。出発地あるいは到着地からの アクセス距離は利用形態(1)の客よりも長い可能性が大 きい。

表-4から、広島空港では他の中国地方の空港よりも形 態(2),(3)の最近隣以外の空港としての利用者が多く、より 広域的利用がされており、中国地方において拠点性が高 いと言える。ただし、九州で拠点性が高いとされている 福岡空港と比較すると、最近隣空港以外としての利用率 は高いものの、利用者数は福岡空港の 4 割程度にとどま っている。

また、各空港の利用客が各ゾーンを発着する航空利用 客に占める割合をそれぞれ図-3〜7に示す。これらより、 岡山空港と宇部空港は他の県の空港に 3 割以上の利用客 を奪われていることがわかる。一方、福岡空港の利用客 は九州地方に限らず新幹線沿いに岡山市周辺まで大きく 広がっており、山口県中部・北部では広島空港の利用率を 上回っている。

（2）利用形態別のサービスレベルの比較 広島空港と福岡空港の利用客が直面している経路のサ 
表-4 各空港の利用形態別旅客数 (人年)

\begin{tabular}{|c|c|c|c|c|c|c|c|c|c|}
\hline \multirow[b]{2}{*}{ 空港】利用形態 } & \multirow{2}{*}{\multicolumn{2}{|c|}{ (1) }} & \multicolumn{4}{|c|}{$(2),(3)$} & \multirow{2}{*}{\multicolumn{2}{|c|}{ (4) }} & \multirow{2}{*}{ 計 } \\
\hline & & & \multicolumn{2}{|c|}{ 最近隣利用 } & \multicolumn{2}{|c|}{ 最近隣以外 } & & & \\
\hline 広島空港 & 986,719 & $66 \%$ & 186,370 & $13 \%$ & 271,260 & $18 \%$ & 46,408 & $3 \%$ & $1,490,758$ \\
\hline 岡山空港 & 275,378 & $78 \%$ & 50,371 & $14 \%$ & 26,732 & $8 \%$ & 2,326 & $1 \%$ & 354,807 \\
\hline 宇部空港 & 339,658 & $73 \%$ & 68,560 & $15 \%$ & 48,413 & $10 \%$ & 6,837 & $1 \%$ & 463,468 \\
\hline 出雲空港 & 263,566 & $65 \%$ & 115,748 & $29 \%$ & 19,849 & $5 \%$ & 5,308 & $1 \%$ & 404,471 \\
\hline 福岡空港 & $7,405,116$ & $77 \%$ & $1,462,561$ & $15 \%$ & $690,273 \vdots$ & $7 \%$ & 92,834 & $1 \%$ & $9,650,784$ \\
\hline
\end{tabular}

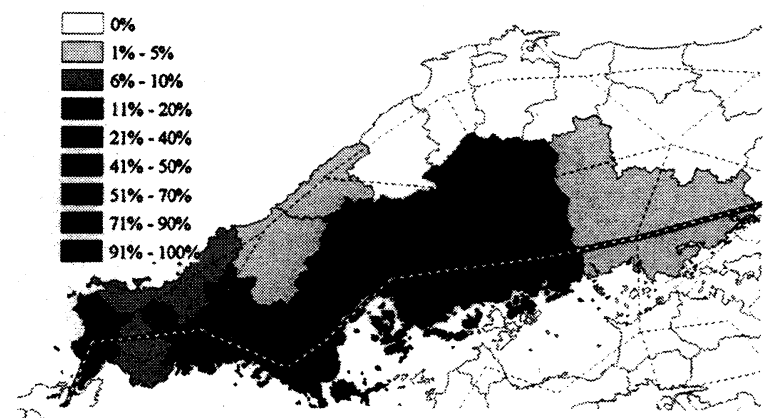

图-3 広島空港の利用客分布

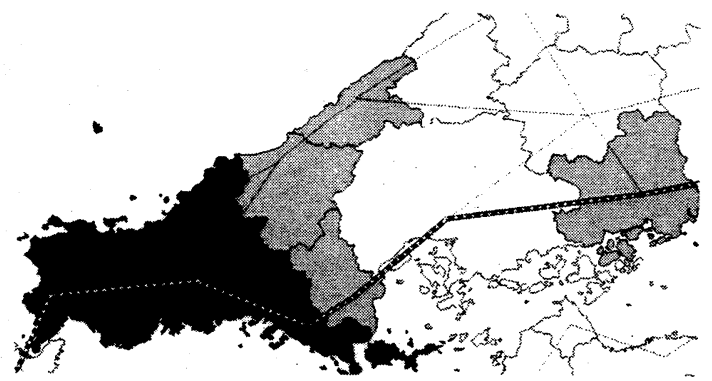

图-5 宇部空港の利用客分布

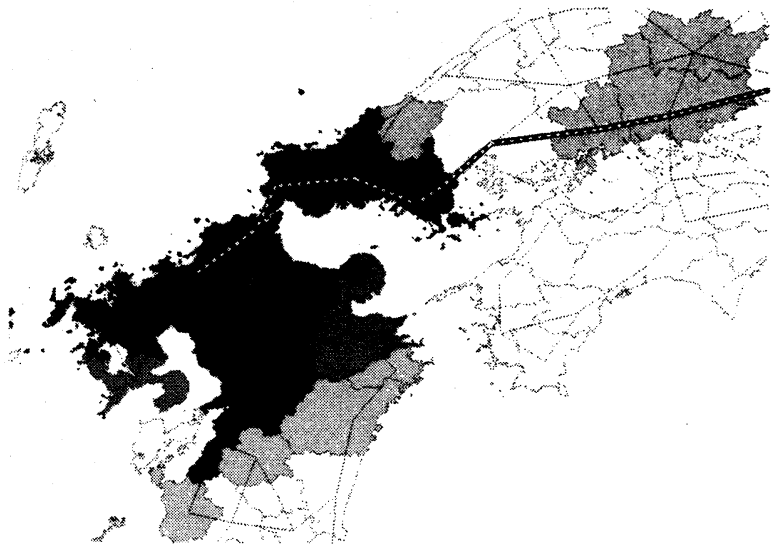

図-7 福岡空港の利用客分布

ービスレベルを比較する。まず $\mathrm{OD}$ ペアを当該空港の利 用形態により区分する。次に、OD ペアごとに当該空港 を利用する経路のサービスレベルを直行経路のサービス レベルで割った值を求める。最後に、利用形態の区分ご とにその平均値を求めた。

図-8に結果を示す。これより、両空港とも、当該空港

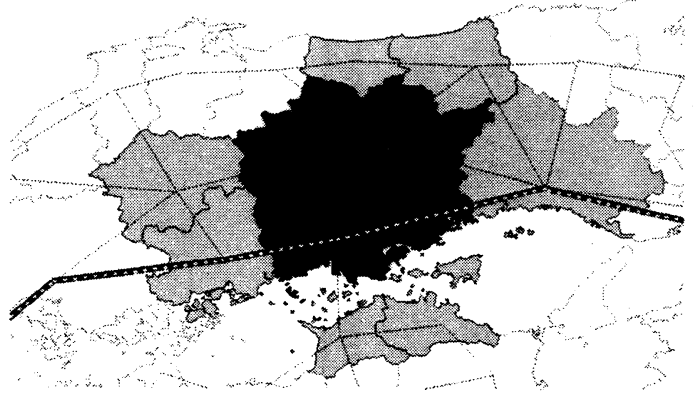

图4 岡山空港の利用客分布

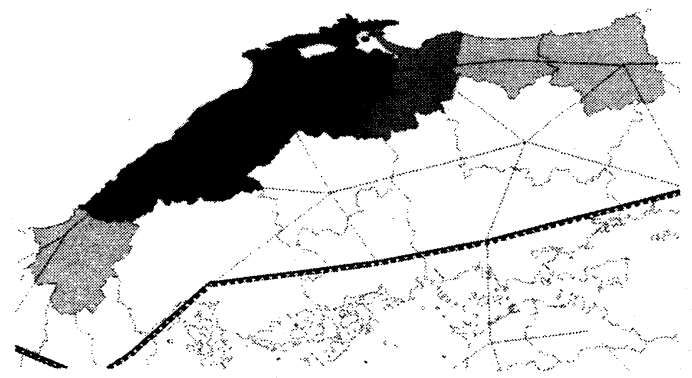

図-6 出雲空港の利用客分布

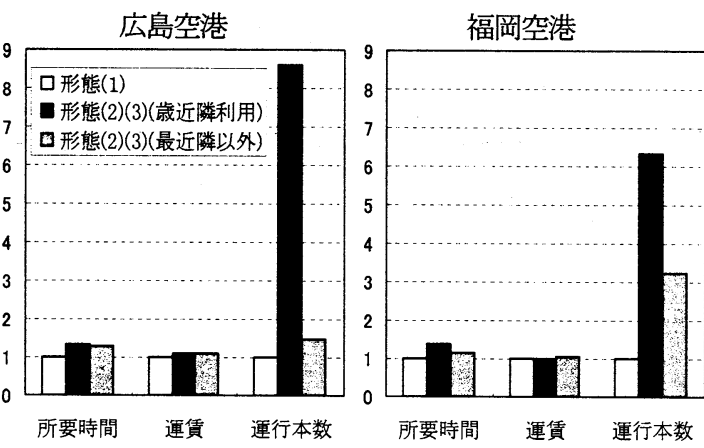

図-8＼cjkstart各空港の利用形態別のサービス水準比

を最近隣空港としない経路は最近隣空港を用いる直通経 路に比べて、所要時間は長く運賃も少し高いが運行本数 は多いここことから、直通航空経路の運行本数が少な い場合に、運行本数が多くスケジュールを立てやすい経 路として両空港を用いる経路が利用されていることがわ かる。

ただし、広島空港は福岡空港と比べると、広島空港を 最近隣以外の空港とする経路のサービスレベルが全体的 
に低く、特に運行頻度が低いことがわかる。これは、現 在の広島空港は JR 山陽本線白市駅からのアクセスが悪 く、遠方からくる旅客が利用しづらくなっているが、逆 に、福岡空港は新幹線が停まる主要駅である博多駅との 連結が良いことを反映している。これに習って、広島空 港への充実したアクセス機関の連携が改善されれば、さ らなる広域的な範囲から利用客の増加が期待できる。

\section{5. 広島空港アクセス改善シミュレーション}

（1）シミュレーションの設定

現在の広島駅から広島空港へのバスは所要 54 分、 1250 円であるが、鉄道アクセスが整備され、所要 34 分、 740 円に改善されたと仮定し、その影響を見る。

対象とする ODペアは、広島、島根、山口県の 13 ゾー ンを出発地、千歳,仙台,羽田の各空港を最近隣空港とする 29 ゾーンを目的地とする全 $377 \mathrm{OD}$ ペアとする。そして、 最近隣空港を利用する最短経路、最近隣以外の空港を利 用する最短経路、鉄道最短経路の 3 経路の分担率を、 3. で示したモデルにより計算することでアクセス改善の影 響を分析する。なお、アクセス交通以外のサービスレベ ルは 1995 年時点の值を用いる。

\section{（2）アクセス改善による影響}

図-9は、出発地側で各県ごとに経路分担率を集計した 結果である。これより、各県とも広島空港利用経路への 転換がみられる。特に、広島空港を利用する経路におい て中距離アクセスに鉄道が利用される可能性が大きいと 考えられる島根県や山口県での分担率の増加分はそれぞ れ $2.4 \% 、 3.3 \%$ あ゙る。これらの值は、鉄道経路の分担率 の減少分(-0.7\%、-1.7\%)よりも大きい值であることから、 鉄道需要の低下にはさほど大きな影響はないことがわか る。

図-10 は、目的地空港ごとに集計した結果である。ア クセス改善によって広島空港利用経路の分担率が 4 〜 $\%$ 上昇するが、特に鉄道経路の利用が少ない千歳空港への 旅客が広島空港の利用経路を選択する可能性が高い。表 -5 は 1995 年時点で各空港間に設定されている便数を示 している。これより、島根県の旅客に限って言えば、千 歳空港や仙台空港まで行く際に直行便が設定されておら ず、居住県外の空港を利用せざるを得ない状況にある。 広島空港へのアクセスが改善されれば、これらの旅客を より確実に獲得できると考えられる。

ここでは、広島空港のアクセス改善のみを考慮してお り、それを原因とする他空港のサービスの低下は考えて いないため、厚生水準は必ず向上する。このことを数量 的に確認するため、対象 ODに関わる利用者のサービス レベルを金銭単位に換算した上で集計する。
- 広島AP利用経路口他の空港利用経路 口鉄道経路

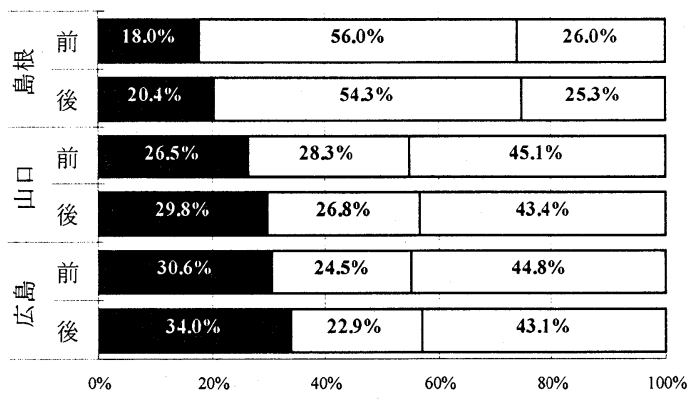

図-9 分担率を出発地側で集計した結果

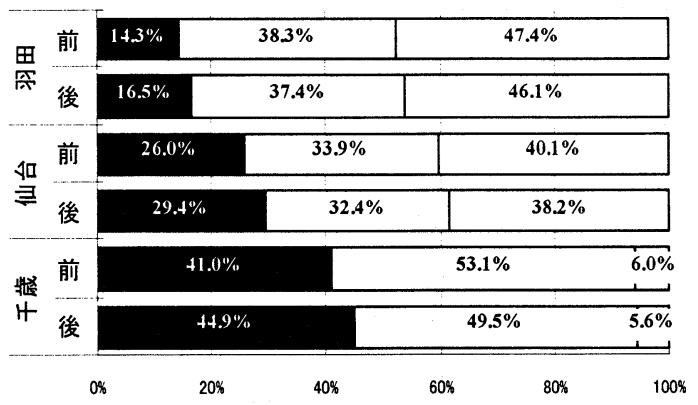

図-10 分担率を目的地側で集計した結果

表-5 空港間の便数(便/日)

\begin{tabular}{|l|r|r|r|}
\hline & 羽田空港 & 仙台空港 & 新千歳空港 \\
\hline 広島空港 & 10 & 1 & 1 \\
\hline 宇部空港 & 5 & $\mathbf{0}$ & 1 \\
\hline 出雲空港 & 4 & $\mathbf{0}$ & $\mathbf{0}$ \\
\hline 石見空港 & 1 & $\mathbf{0}$ & $\mathbf{0}$ \\
\hline
\end{tabular}

$$
P W=\frac{1}{\left|\beta_{2}\right|} \sum_{O D} L O S_{O D} \times T_{O D}
$$

$$
\begin{array}{ll}
P W & : \text { 対象地域の厚生 } \\
T_{O D} & : \text { OD 間の実流動量 } \\
\beta_{2} & : \text { 選択モデルに狩賃のパラメータ(仕事 } \\
& \text { 目的),(単位; } 1 / \text { 万円) } \\
L O S_{O D} & : \text { OD 間のサービス水準 }
\end{array}
$$

$\mathrm{OD}$ 間のサービス水準は利用可能な経路のサービス水 準の合成值として与える(式(4))。

$$
\operatorname{LOS}_{O D}=\sum_{I} \exp \left(V_{i}\right)
$$

計算の結果、アクセス改善により式(3)の值は 222.6 億 円/年から 254.5 億円/年となり 14.4\%高い值を示すことが

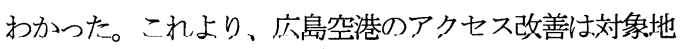
域に大きな効果をもたらすことが確認できた。 


\section{6. おわりに}

（1）地方空港のセールス戦略

本研究では、ケーススタディとして広島空港のアクセ ス改善シミュレーションを行い、これによって広島空港 の広域的利用が促進する可能性があることを示した。地 方空港が今後他都市圈から広域的に旅客を集めるために は、従来加考慮されてきた母都市との間の短距離のア クセスばかりでなく、都市間をまたぐ中距離のアクセス を整備していく必要がある。

それには、都市間鉄道サービスの乗り入れや連絡の改 善だけでなく、都市間高速バスの空港乗り入れや空港ア クセスバスとの乗り継ぎ利便性の改善が重要となる。ま た、アクセスにおける自家用車の利用も考慮する必要が ある。実際鳥取県の中部および南部の住民が東京圈に向 かう際には、便数が多く割引サービスが充実している岡 山空港まで自家用車でアクセスし、無料駐車場を利用す るケースが多いとされている。

県外から来る旅客に対する情報提供、予約サービスも 重要である。彼らは当該空港やアクセスサービスについ て限られた知識しか有していないと考えられ、案内や情 報提供の充実が必要である。さらに自家用車でのアクセ スにおいては、駐車場が安価にしかも確実に利用できる ことが重要となる。他府県ナンバーへの料金優遇制度、 あるいは事前の駐車場予約制度も有効な空港セールスの 手段となる可能性がある。

\section{(2) まとめ}

航空交通サービスがもつポジティブ・フィードバック の構造を考えれば、地方空港は今後、旅客をめぐる競争 に巻き込まれることは必至であり、空港セールスのため の戦略を立て、実行に移寸ことが求められる。また、こ のような競争に負けた空港では、ポジティブ・フィーバッ クがマイナスに作用しサービスレベルの低下を招く恐机 もある。このような可能性を踏まえた複数空港のすみ分 けについても、今後検討していくことが望まれる。

本研究では航空サービスの利用形態の分類を行い、空 港別のサービスレベルの影響を分析した。更に、中距離 アクセスと空港の広域的利用の関係を示した。今後、既 に利用可能となっている 2000 年の旅客純流動調查デー 夕の分析を引き続き行う必要がある。

\section{参考文献}

1）花岡伸也・有村幹治 : 「旅客のアクセス利便性からみた複 数空港の機能分担の評価」土木計画学研究·講演集、Vol.18、 No.4、pp675-680、2001

2）枦元淳平 - 奥村誠 ・ 塚井誠人 ・村上直樹 : 都市間旅客の マルチモーダル利用の実態」, 日本機械学会第 10 回鉄道技 術連合シンポジウム講演·論文集, pp.429-430，2003.

3）呪玉健・若井郁次郎：「空港アクセスについて」、士木計画 学研究·講演集、No.17, pp55-56、1995.

4）岡山信広・武藤雅威・内山久雄 :「幹線旅客純流動デー夕 に基づいた空港アクセス特性に関する研究」土木計画学 研究·講演集、No.21(1)、pp469-472、1998.

5）武藤雅威・内山久雄 :「新幹線と航空の競合時代を反映し た国内幹線旅客交通の現状と展望」、運輸政策研究、 Vol.4.No.1、pp2-7、2001.

6）本多均・加藤浩徳 - 金相奉 - 金本良嗣 :「空港整備事業の 費用対効果分析小、運輸政策研究、Vol.3.No.1、pp23-33、2000.

7）塚田悟之・高田邦道・山口泰男 :「等時線図を用いた空港 アクセスの分析と評価」土木計画学研究·講演集、No.18(1), pp377-380、1995.

8）森川高行・荻野成康 :「中部新国際空港のアクセス交通に 関する研究」土木計画学研究·講演集、No.17, pp57-60、 1995.

9）高瀬奎夫・森川高行・阿野貴史・長澤貴憲 : 「モデルの移 転可能性に焦点をあてた空港アクセス交通の非集計分析」、 土木計画学研究·論文集、No.17、pp855-861、2000.

10）浦田康滋・杉本直彰・田村亨・斉藤和夫：「マルチ・エアポ 一ト・システムのモデル化 複数空港が存在する地域の空 港選択構造-小、土木計画学研究·論文集、No.14, pp765-772、 1997.

11）枦元淳平・塚井誠人・奥村誠：「複数経路を考慮した鉄道・ 航空ネットワークの評価、土木計画学研究・論文集、No.20、 pp.255-260、2003. 


\section{地方空港アクセスが広域的利用に与える影響*}

村上直樹**・枦元淳平 $* * *$ 奥村 誠****・塚井誠人*****

わが国において、航空は長距離の都市間旅客交通の主要な手段となっている。特に業務旅客にとって便数 が重要な経路選択要因であり、少し離れた空港に出向いて便数の多い路線を利用するという広域的な利用行 動が多く観察される。本研究では初めに、第2回幹線旅客純流動調査（1995年）のデータを集計し、我が国に おける空港利用の実態を明らかにするとともに、航空利用客の経路選択の分析を行う。旅客の経路選択モデ ルを構築することで、便数の影響力が強いことを示す。次に、中国地方の各空港の利用形態を明らかにする。 最後に、広島空港へのアクセス改善に関するシミュレーションを行い、周辺の都市圈からの広域利用に及ぼ す影響を分析する。

\section{Local Airport Usage from Wider Area Affected by Access Service Area Affected*}

By Naoki MURAKAMI-Junpei HAZEMOTO-Makoto OKUMURA•Makoto TSUKAI

In Japan, aviation service become main mode for the long-distance passenger trips. Many passengers now use flights from a little separated airport from origin area if higher frequency is available than from the nearest airport. In this research, the net passenger trip data (1995) is aggregated to clarify the actual use of airports in local areas. Next, logit models selecting route from (1) direct flight, (2) flight with longer surface access and (3) whole railway route are estimated for each trip purpose. It shows that frequency is an important path selection factor especially for business passengers. After clarifying the use of each airport in Chugoku Region, a simulation about the access improvement to the Hiroshima airport is performed, and the increase of the use from the wider surrounding city zones is analyzed. 